\title{
Veiled Politics: Muslim Women's Visibility and Their Use in European Countries' Political Life
}

\author{
Anna Vanzan \\ School of Languages and Cultures for International Communication and Cooperation, University of Milan, \\ Piazza I. Montanelli 1, Sesto S. Giovanni, 20100 Milan, Italy; anna.vanzan@unimi.it; Tel.: +39-800-188-128 \\ Academic Editor: Nancy A. Naples \\ Received: 11 January 2016; Accepted: 11 May 2016; Published: 18 May 2016
}

\begin{abstract}
One of the many disastrous consequences of the tragic events of 9/11 is the war waged by the neocolonialists in order to "liberate" Muslim women. This gender-based war stands on a series of pillars, such as the presumption that Western civilization offers women a great deal of privileges, while Muslim culture gives none. Therefore, it would be logical to suppose that, because of the many opportunities the West grants to Muslim women who reside there, the latter may have an active role in the local political process. However, Muslim women have scarce visibility in European political life, and their presence is sometimes merely instrumental to some party: in most cases, women are coopted because they are a good sample of "secular Muslims" (i.e., they do not wear the hijab, i.e., the veil and a modest attire); in others, they are appointed because they are veiled and can therefore become a good vehicle in order to win the support both of the Muslim community and of its sympathizers. In this paper, I will analyze some crucial aspects of Muslim women's formal political participation in some European countries; in addition, I will focus on the Italian case with the help of a series of interviews with Muslim women who play an active role in local political councils. The study shows how in European politics, Muslim women can become a commodity even when they stand out as rising political individuals; but also how they fight to gain visibility and public recognition, in spite of the tense situation and of the rampant Islamophobia.
\end{abstract}

Keywords: Muslim women and European politics; Muslim women's political activity in Europe; Islamophobia; Muslim women in Europe; the veil issue

\section{Introduction}

In the post-9/11 era, the complexity of the relation between European countries and their Muslim citizens has deepened substantially. Global events and terrorist attacks in the heart of Europe have contributed to the reshaping of Europeans' attitude towards Muslims. At the same time, the European Union's "official" position has remained ambiguous. This complex situation reverberates on the attitude both the EU and single European countries show towards Muslim women: on the one hand, they seem willing to coopt Muslim women in order to have them as allies against Islamists' threat. On the other hand, the general mistrust towards Islam and its practitioners is reinforced by the widespread belief that Muslim women represent a deviation from the acceptable European female model. This shifting attitude is proven by the profiles of Muslim women invited by some European parties as representatives in local councils or in higher political institutions. As I will try to show, political agencies' selection of Muslim women to be elected in their groups is instrumental, as the majority of them wants to shape a "Western-European" model of Muslim woman. Others wish to show their open-mindedness by flaunting their respect for minorities, i.e., those principles considered to be Western prerogatives vis-à-vis "Muslim intolerance".

The brief history of Muslim women's participation in European political institutions (in Germany and in the UK) is very significant, as we will see hereafter. 
On 16 December 2013, Aydan Özoğuz was the first woman of Turkish descent to become Minister in Germany. She was appointed as Commissioner for Immigration, Refugees and Integration after she served first as member of the Hamburg Parliament (2001-2008) and then of the Bundestag (2009-present). Aydan Özoğuz, born in Germany and married to Michael Neumann, Senator of Interior Affairs from SPD (Social Democratic Party) in the state government of Hamburg, has publicly distanced herself from her brothers Yavuz Özoğuz and Gürhan Özoğuz, who run the Islamist Internet site Muslim-Markt and are considered "radical Islamists" [1].

In 2013, other Turkish women entered the Bundestag, namely Cemila Yusuf (born in Greece), who became the first Muslim woman to be elected in the center-right Christian Democratic Party, Cansel Kiziltepe (born in Germany) and Gülistan Yüksel (born in Turkey), who served in the Social Democratic Party, and Azize Tank (born in Turkey), who served in the Left Party. These ladies went to join other Turkish female parliamentarians Ekin Deligöz (born in Turkey), who belonged to the Green Party, and Sevim Dağdelen (born in Germany), also of the Left Party.

One could say that Muslim women are well represented in German politics; however, the summoned women are openly secular with the only exception of Cemila Yusuf, who publicly identifies herself as Muslim. We might label them all, aside from Cemila Yusuf, "secular Muslims", a neologism that mainly addresses those who believe in Islam, but who do not practice the religion. In addition, they seem to be more representative of their ethnic (Turkish) group rather than their religious bend, as they belong to the largest non-national ethnic group living in Germany [2].

The same trend is confirmed by the French experience: most of the Muslim female politicians are of North African origins, as the Maghrebis constitute the biggest non-European ethnic group in France [3]. Here, too, most Muslim women politicians are openly secular, the most famous being Moroccan-Algerian Rachida Dati (born in France), who in 2007 became the first Maghreb woman to become Minister (of Justice). Her secular position was also confirmed by her private life: she is (still) unmarried with a child whose father's identity is unknown, one of the reasons why she has become a favorite among international tabloids.

The same principle is true in Great Britain, where, so far, the active Muslim women politicians mostly come from the sub-continent (Pakistan and Bangladesh), i.e., the biggest source of migration to the U.K. In the British Isles, however, we find some differences with the rest of Europe as, alongside more "secular" female politicians, we also find women whose religious background is their hallmark and whose politics are centered on their belonging to the Muslim community. In particular, I refer to the first Muslim women to become Members of the British Parliament, Pakistan barrister Yasmina Qureshi, who is the President of the Muslim Lawyers Association, and Shabana Mahmoud, who hit the news because she publicly supported two campaigns, i.e., the boycotting of Israeli products [4] and the revocation of the ban on wearing the niqab (the veil covering the whole face except the eyes) at Birmingham Metropolitan College [5]. Some of these women, however, paid a big price for their commitment to the Muslim cause: this was the case of Bengali Rushanara Ali, who, after four years of serving as MP for the Labour Party, had to resign in September 2014 as she refused to support the House of Commons' motion in favor of military action in Iraq [6].

Before we proceed, however, we need to address a certain issue: whom do we consider a Muslim; and, moreover, whom do we consider a "Muslim woman"?

\section{Muslim Women: From Definition to Their Presence as Such in Politics}

For millions of people, Islam has become the central element in defining themselves and the group to which they belong. We take for granted that the term Muslim is applicable only to those who follow God's revelation through the Prophet Mohammad and who obey His commands. Consequently, a Muslim must act according to Islam's teachings, such as observing preying, fasting and the like.

Naturally, being a Muslim is subject to historical mutations [7], and the events following 9/11 have highly contributed to Muslims' rethinking their way to be Muslims. Muslim women in particular are subject to much pressure both internally (in the umma, i.e., the global Muslim community) and 
externally. As a matter of fact, their behavior constitutes the constant target of their group, mainly on behalf of the patriarchs who want women to be the chaste flag-bearers of their civilization. At the same time, outside the umma, the Western gaze has turned Muslim women into the main symbol of the "misogyny and backwardness" of the Islamic religion.

In the difficult historical period we have been experiencing since $9 / 11$, the Western world has a constant need to find women who define themselves as Muslim while showing their loyalty to the values it praises, such as modernity, secularism (i.e., the separation between State and religion), freedom of dress (i.e., adoption of Western dress codes or, in the case women want to wear the veil, it must not be too concealing), respect of human/women's rights, respect of LGBTQ people, and so on.

However, more often than not, the women chosen by the West as "symbolic Muslims", rather than functioning as bridges and as cultural mediators between "Us" and "Them", have turned into the representation of the incompatibility between the West and Muslim world. The war on terror, by privileging the view of Islam as a threat to the rest of the world and the discourse on Muslim women as the victims of their own patriarchal religion, has promoted a "Muslim woman" who is resentfully antagonistic to Islam. Therefore, in Europe and in the U.S., Muslim women promoted by the West as such speak against Islam and its patriarchs, distance themselves from their Muslim origins and enforce the idea that Islam is "a church" against women.

Though I am far from affirming that the issue of Muslim women represents the proof of the incompatibility between the West and the world of Islam, it is nevertheless true that in the last few decades, the West has favored a number of women with MENA (Middle East and North Africa) origins who serve as "native informants" by denouncing every mishap that afflicts women in that area as an offshoot of Islamic religion and civilization. There is an abundant literature on the subject [8-12]: its authors, who, interestingly enough, are Muslim themselves, are very critical of this process and of the women who comply with the stereotype of the "poor Muslim woman" and reinforce it. The women in question are mostly authors of (pseudo)autobiographies or sensational journalism in which they use the troubles they experienced as a universal claim that Islam is irreconcilable with basic women's rights. Writers such as Bengali Taslima Nasrin, Iranian Azar Nafisi and Ugandan Irshad Manji, to name some of the most famous, have become spokespeople in favor of the supporters of the "clash of civilizations" theory.

These token women have contributed to create a gender-based Islamophobia while, at the same time, paving a good career for themselves. Additionally, some of them succeed in entering the political arena and serving in parties with a xenophobic agenda. Perhaps the most famous case for this is represented by Ayaan Hirsi Ali, the Somali-born activist (1969) who obtained political asylum in the Netherlands (1992), where in 2003, she was elected member of Parliament as representative of the People's Party for Freedom and Democracy. Afterwards, Hirsi Ali abandoned the Netherlands to migrate to the U.S.; as a matter of fact, after a channel had discovered that she had fabricated most of her history as an "oppressed Muslim woman", the Dutch Parliament underwent a crisis, and Hirsi Ali had to resign $[13,14]$. Nevertheless, Hirsi Ali continued to churn out best-selling books on the incompatibility between Islam and democracy/feminism/gender equality, etc., and, consequently, to be globally regarded "as another Spinoza who battered dogmatic religious beliefs throughout his life" [15]. In the U.S., she was even granted several coveted positions and honors. Ironically, she was recently (December 2015) prized for her outspoken position as a "reformist Muslim" while she has repetitively and publicly proclaimed to be an atheist [16].

Hirsi Ali is a very interesting case as she shows the different, but substantially Manichean perception Westerners have regarding Muslim women: they are all victims of their religion with the exception of the ones who denounce and abandon their religion. Naturally, Ali, and the other writers/intellectuals/politicians who share her position, triggered a passionate debate among scholars not only in the U.S., but also in Europe. While Hirsi Ali's golden destiny shows the general Westerns' need to find "authentic" Muslim women to accomplish their political agenda, in a Europe shattered by a wave of rampant Islamophobia, many political parties wanted to support their fight against Islam 
and the Muslims by adding to their ranks Muslim women with a strong bias against Islam. Thus, they could prove that Islam is really a "religion against women" because this theory is supported by Muslim women who have experienced the Islamic misogynistic bent. In Italy, for example, we may relate the case of Souad Sbai, a woman of Moroccan origins (Casablanca 1961), but who has lived in Italy as an Italian citizen for nearly 40 years. She received her university degree in Italy and was trained as a journalist there. Married to an Italian politician of a right wing party, Sbai was promoted as a Moroccan/Muslim woman denouncing, via newspapers, blogs and popular books, the abuses Muslim women are subject to because they are Muslim. She was granted important governmental appointments at least since 2007, then she became the first Muslim Parliamentarian, and though she has changed political coalition many times and is not a member of Parliament any longer, she still revolves around Italy's political mainstream, now as an active member of the xenophobic Lega Party. She advertises herself as "a great expert of the Muslim world" [17] and is much sought by TV talk shows in which, also symbolically, she sits on the side of Islam denigrators, vis-à-vis more balanced guests.

\section{The European Union and Muslim Women: What the EU Really Does (Doesn't) for Them}

Here, I will briefly evaluate the European Union's (EU) policy towards Muslim women. It is actually quite difficult to place the EU and the category of "Muslim women" on the same level: the former is a supranational institution subject to international laws, which also establishes laws and rules that must be obeyed by its citizens; while the latter is an extremely fluid category that incorporates a variety of inhomogeneous subjects who live in territories both under the EU's authority and, mostly, outside it. In the last twenty years, the EU has showed a particular interest towards both the women who live in the south Mediterranean shores and those who abide in a European country [18]. Muslim women who live in Europe constitute, in the EU's eyes, a "minority". This approach has been favored by the Balkan wars that afflicted the former Yugoslavia in the 1990s and that targeted with particular violence Bosnian Muslim women.

The EU adopts a parallel approach by treating "Muslim women" as part of the "Muslim issues", i.e., as a problem of immigration and/or integration within its borders; needless to say, this approach is wrong, as it overlooks the fact that many Muslims are EU citizens and, as such, entitled to the same treatment other European citizens enjoy. Slowly, but inexorably, the increasing number of Muslims of both sexes in Europe has encouraged the EU to tackle problems such as domestic violence inside the Muslim community, the issue of the veil in the public sphere and, finally, the widespread Islamophobia that often targets women because, since they wear a veil in public, they are the most visible mark of the Muslim presence [19]. However, when one examines the EU's official website to discover what has truly been done, one finds an interminable series of projects, reports, statements, opinions, roadmaps, reviews, and so on, that look to be more theoretical in nature rather than substantial. Muslim women apparently fit into several programs that the European Union tailored for all women, such as: the PROGRESS programme, the EU Gender Institute, the EU network of women in decision-making, The Advisory Committee on Equal Opportunities of Women and Men, among others. These programs are meant to organize actions against discrimination, to build equality between men and women and to take measures against social exclusion [20].

The paradoxical relation between the EU and Muslim women is also determined by the post 9/11 times: if, on the one hand, some political actors try to facilitate the social and economic "integration" of Muslims, on the other hand, the war on terror that has stretched from the U.S. to Europe and its concern about terrorism and security provoke restrictions of religious liberties in the public space. Muslim women and their external display of religious identity (i.e., the hijab) are viewed not only as obstacles to secularism and modernity or as the unwillingness to accept Western/European values as was the case before, but more significantly, as one of the symbols of Muslim's "hate" towards Western civilization and as proof they seek to destroy it.

When we introduce the hijab issue within the context of EU legislation and rules, it takes an important twist because it shows that, though the EU declares its willingness to eradicate any form 
of violence against Muslim women, the practical outcome is in fact quite different. A proof of this is the stand the European Court of Human Rights (ECHR) took towards the controversial issue of the veil. The ECHR was created by the Council of Europe with the aim to turn it into the most effective and advanced supranational human rights regime in the world [21]. The impact of ECHR decisions is crucial, because European countries have to follow them in order to find solutions to their internal issues.

Among other sensitive issues, the ECHR had dealt with lawsuits filled by people banned from wearing religious symbols both in Europe and even outside (i.e., in Turkey, as we will see). In particular, between 2001 and 2011, twelve lawsuits addressed by women living in Turkey, France and Switzerland who were not allowed to wear the veil in public and who considered themselves deprived of their religious rights were presented to the ECHR, but none of them were accepted [22,23]. It is interesting to see how the European Court's judgments show that veiled women's religious freedom has been limited in the name of secularism and even of gender equality. Moreover, the ECHR, by interpreting the concept of secularism as the opposite of Islam's intolerance, has helped to reinforce the popular and widespread view in the West that Islam is a religion against women and incompatible with concepts, such as tolerance, human rights, gender equality, and so on. At the same time, the European Court, while proclaiming to be an impartial instrument to protect human rights, has repetitively dismissed the requests of women who wear the Islamic headscarf as a chosen individual act of religious freedom that should be protected and safeguarded.

In any case, the issue of the veil is crucial: it continues to receive widespread media attention; it has become the symbol of the "Muslim invasion" in Europe and the watershed between Us (Westerners) and Them (Muslims); and last but not least, it has become a potentially profitable political gadget.

\section{Turning the Veiled Woman into Political Propaganda: The Danish Case}

In this section, I will take into consideration some case studies of Muslim women who have been coopted as political agents in two European countries, Denmark and Italy. In fact, a common European political agenda is still missing in several fields, including the relationship between European and Muslim communities. So far, each European country deals with Muslim subjects and practices differently, according to local traditions, rules, legal bounds and visions on religion, culture and human rights. Though Islam is a common problem, we need to examine single States' policies in order to have more insight on Muslim women's political role in Europe.

I have purposely chosen two countries that have a rather diverse history as per what concerns women's rights. In Denmark, the revised 1915 Constitution gave women the vote, and a series of equal opportunity laws in the 1920s built on that initial foundation. Since then, women became legally equal to men; they had the right to vote, access to education and work and held the same marital rights and obligations. Denmark boasts a secular society and is globally considered as a "free" country in terms of sexual ethics and customs. In Italy, in spite of an active feminist movement, women gained the right to vote only in 1946, and even now, they have to face difficulties in fighting against both an ever-green machismo and a still widespread bigoted mentality.

In 2005, The Red-Green Alliance (Enhedslisten), the most left-wing party in Denmark, nominated as deputy representative for the Odense city council, Asmaa Abdol-Hamid (UAE 1981), a social worker of Palestinian origins who had been living in Denmark since the age of 14 [24]. After two years (2007), Asmaa declared her intention to run for the Parliament and thus threw "the country into a heated political debate on whether a practicing Muslim woman can speak in Parliament wearing a headscarf" [25]. Moreover, her decision not to shake the hand of male colleagues, but rather to greet them by placing her hand over her heart sparked national debate [26]. However, basically, she was contested because she would wear a headscarf in front of the national audience. Therefore, why had her party decided to nominate her? Asmaa was only 24 when she was nominated, and had she won, she would have been the youngest female MP in the Danish Parliament. She had surely not been chosen for her political experience. Perhaps one of the reasons could be because, as Asmaa 
acknowledged, "It isn't a secret that wearing the headscarf in general made headlines all around Europe and the Arab world, and that it became a chance for discussion about the rights of women, equality, and opportunities" ([26], p. 22). Asmaa seemed to suggest that a veiled politician's presence can favor the discussion about Muslim women's rights; however, one could cynically maintain the opposite, i.e., that a party decided to have a veiled candidate because it would have provoked uproar and therefore a good way to create free publicity and enhance the elections campaign. Between 2005 and 2007, in fact, Denmark became the arena of a passionate debate caused by the "cartoon crisis", following the series of twelve cartoons on the Prophet Muhammad's life published by the newspaper Jylland-Posten (September 2005) and judged blasphemous by most of the Muslim community. Violent protests erupted in Denmark initially and then everywhere, finally provoking an international crisis [27]. A few months later, Asmaa Abdol-Hamid became the presenter of a TV talk show called Adam E Asmaa. The talk show aimed to examine the cultural and religious gap between Islam and the West, focusing on politics, society and integration, especially by riding the wave of the "cartoon crises". On TV, Asmaa appeared with the veil on, and her outfit triggered a new surge of protest. As she recounts:

[... ] the reception was harshly negative. I remember some of the old feminists protesting my role as a broadcaster wearing a headscarf. They claimed that the headscarf was a symbol of oppression, and so asked the channel to immediately stop my employment. Eventually, the issue attracted international attention, and journalists, not only from Denmark but from around the world, flocked to interview me. My phone didn't stop ringing. The paradox was that while some journalists considered the story a huge success regarding opportunities for women in the labor market, others viewed it as a crisis of women's liberation ([26], p. 21).

Therefore, Asmaa's words did not seem too important; the decisive issue was her veil. Ironically, this would put her in the same position of those TV presenters who are chosen for their beauty rather than for their intelligence: be it veiled or naked, the woman's body is globally used as an advertising factor. However, in Asmaa's case, a political struggle was waged through her body, a struggle between two conflicting ways to see (Muslim) women's freedom and in order to define "who is more civilized than whom" [28]. Asmaa was particularly struck by the criticism coming from Danish feminists who said she promoted "gender apartheid":

I thought to myself: Did they (the feminists criticizing me) forget that they once had to fight about the right to choose? Did they forget how society judged their demands? Isn't it the same when they claim that Muslim women wearing the scarf are oppressed by men, religion, or a specific culture? Who is judging now? Did they ask those women what they think or feel, and whether they have made their own choices or not? ([26], p. 22).

In reality, what feminists and the larger public contested was Asmaa's unwillingness to integrate: as has become common knowledge, there is a narrative (that unfortunately most feminists share) that portrays the veil as a symbol of backwardness and of Muslims' obvious inability/refusal to integrate. However, integration, as it is commonly understood, is a flimsy concept, a cultural trait, and as such, Asmaa Abdol-Hamid denounced it:

I don't like the word 'integration'. Everyone uses the word without being able to make any clear-cut definition. Ethnic minorities are not a problem in themselves; when identifying reasons for the lack of integration in Denmark, I prefer to talk about social classes and look at people's class background rather than their ethnic identity [24,29].

In any case, Asmaa's veil in fact damaged the Red-Green Alliance: while some of the party's members had chosen her with the hope to increase their votes, the majority of her colleagues were against her candidacy. Many left-wing people declared to withdraw their support from the Enhedslisten [30], and inside the party, even "an anti-religious network was created within the party with the stated goal of turning the party into a solely atheist party with a materialist-Marxist basis" [31]. 
As a matter of fact, the elections with Asmaa Abdol-Hamid as a candidate resulted in a disaster for the Red-Green Party, that scored a miserable 2.2\%, compared to the $3.4 \%$ in the 2005 parliamentary elections, the lowest since the party's activity (i.e., 1994). Asmaa, of course, was not elected. Neither was she in the European elections, in which Enhedslisten, though never directly contested, participated in support of other coalitions; the party got the lowest vote rate ever [32].

Since then, Asmaa Abdol-Hamid has virtually disappeared from the Danish political scene and, with the exception of her activity as media commentator, she has ceased to be a public figure. Though she lives in a North European country known to be the home of civilization, liberty and civil rights, she has paid for her appearance even before she could prove she was apt at doing her job as a politician. Her veil functioned as minarets and mosques do, i.e., it was viewed as a rejection of Western democratic values and a direct threat to the myth of Danish women: "liberated and free".

It is interesting to note that in the same elections in 2007, the Socialist People's Party (SF) presented another candidate of Muslim background, namely Özlem Sara Cekic, a nurse of Turkish origins who won the PM seat. Cekic portrayed herself as a progressive Muslim woman from a working-class background [33]. Needless to say, Özlem Sara Cekic would not wear any veil.

\section{Italian Veils in the Italian Context}

In Italy, Islam is the second largest religion. Data about the percentage of Muslims in the country is rather discordant, depending on the institution collecting it; however, one might say that Muslims currently represent $2 \%$ of the entire population, about $1,500,000$ individuals [34]. Statistics might not appear important, but we have to keep in mind that Italy is the residence of the highest Catholic authority, the Pope [35]. There are also many Italian converts to Islam, both to the Sunni and to the Shi'a bend, and actually, starting in the late 1980s, male converts from Catholicism to Islam have been the first to interact with the local/Italian communities. Later, they were substituted by other social/political actors (Islamic scholars, sociologists, and so on), but the fact that they have Italian citizenship [36] places them in a privileged position with regards to the accessibility to the world of politics. Therefore, one would expect Italian Muslims to play a large role in the local politics, but it was only as late as the mid-2000s that Muslims and immigrant minorities began to appear in politics, both locally and in parliament. In the April 2008 elections, Muslims were both sought and rejected in their participation. Almost all party lists presented at least one Muslim candidate, including the xenophobic Lega Party [37]. However, fewer immigrants than expected made it to the electoral lists for the Italian parliament and senate [38], and most of the elected were "regretful Muslims", such as the already mentioned Moroccan journalist Souad Sbai.

The situation in which those elections took place heavily resented the implication of the widespread Islamophobia: many in Italy were worried not only by the international air of tension [38], but also by the increasing presence of immigrants and by the boost in crimes allegedly committed by foreigners. Even the Consulta Islamica, an institution promoted in 2002 by the Ministry of the Home Office, which is responsible for counseling the Italian government on various issues concerning Muslim people residing in the country, did not help: the Consulta was born under bad auspices, particularly because some of its members were either openly notorious Islamophobes or individuals whom most Muslims would hardly identify as their representatives [39].

Nevertheless, in the same years, the young generation of Muslims born in Italy (children of immigrants or of inter-ethnic/inter-faith marriages born in Italy or brought to Italy as babies/children), often called G2 (Generation 2), was becoming more and more aware of the necessity to become visible not only in society, but also in the political arena. Of course, the road towards local political appointment is easier than becoming an MP, and it is in the former that Muslim women have been carving their path to political representation. Moreover, in Italy, as well as in other European countries, the leftist parties have shown to be more prone than right wing parties to enroll among their ranks Muslim candidates, including veiled women. 
In the 2013 elections, Muslims were enlisted in several lists presented by the Democratic Party (PD). Only one young man managed to enter into Parliament [40]. However, in a town in the suburbs of the rich and industrialized city of Milano, a young veiled woman, Rassmea Salah, was elected for local council. Here follows her story, which I collected through a series of informal interviews I held with her [41,42].

\section{Young, Female and Muslim: How to Fit Three Identities}

Rassmea was born in Italy to an Italian mother and Egyptian father, in a family in which religion was not a matter of constriction: in fact, the brother embraced the Catholic faith, while Rassmea become a passionate Muslim. In addition to a degree in Cultural Mediation, Rassmea has pursued studies in Qur'anic exegesis in Egypt and in Saudi Arabia. In the last few years, she has been working as a fundraiser for an Islamic NGO (Islamic Relief). In addition, she has been particularly active against female genital mutilations, a phenomenon still quite widespread in her father's country and whose effects can be felt in Italy, as well, as a consequence of migration. I first met Rassmea some years ago while I was researching Islamic Feminism and believe that her position regarding Female Genital Mutilation (FMG) and its connection to Islam, as well as her position on Islamic feminism are particularly interesting:

FGM is not an Islamic practice, not only because there is no holy text that prescribes it, but also because Islam is the religion of moderation. Islam provided women with full rights since its beginning; hence, Islamic feminism is just the discovery that these rights are out there. In this sense, Islamic feminism places itself in an opposite position with respect to Western feminism: the latter represents a leap forward, while Islamic feminism has to turn back and discover something which already existed centuries ago. And Islamic feminists know very well that FGM is not an Islamic practice! [43].

Thus, even before entering into politics, Rassmea was already working for a political project, i.e., to show Muslims and Catholics, with whom she collaborated in an anti-FGM project, that these awful practices are not Islamic. Being a young educated Muslim woman activist and feminist, Rassmea's work can be very influential within Italian society, and many now have come to distinguish between FGM as a purely cultural practice and Islam as a religion. This awareness is being successfully disseminated in schools, in the media and other public venues and so helps debunk stereotypes about the third generation of Muslims presently coming of age.

Rassmea believes in the compassionate message of Islam that embraces everybody, women included, and believes that the veil (that she wears), when imposed, becomes a political weapon utilized by men. So much so, she adds, that if she had been forced to use it, she would have hated her religion [44].

While still a student at Milan University, Rassmea developed an interest for the right to citizenship and began to write about it in the online newspaper Yalla Italia, whose editors are mostly G2 men and women. Almost simultaneously, she began to cooperate with a local section of the Democratic Party for which she carried out low profile activities, such as flyering at meetings, working as a poll officer, and so on. With the approaching 2013 elections, the Democratic Party asked her to run for the regional council [45]: they wanted a "new Italian", i.e., a young representative of the young generation as an answer to the general lamentations about Italian political gerontocracy [46]. At the time, Rassmea was only thirty years old and believed that the appointment was far too heavy: "I would have attracted too much attention" she says [47].

However, then, Bresso (Rassmea's little town) was having elections to appoint the new mayor, and the town council and the local Democratic Party's committee urged Rassmea to run. She accepted, but did not run an election campaign; it was just her mother who sent some flyers around. Rassmea did not win immediately, but she was retrieved after some months because one of the elected members 
of the council had resigned: "In any case, I did not think I could win, I knew nobody in Bresso though I lived there because most of my life was in Milan", she said precisely.

The media immediately advertised her as "the first town councilor wearing a veil" [48]: nobody seemed interested in Rassmea's skills, but rather, in her image, as was shown by the vast majority of the headlines that depicted her mainly as a "Muslim veiled woman".

The municipality gave her the task to work on the commission on immigration, but Rassmea refused:

They even wanted me to chair the commission, but I was not interested in it, I did not want to be "the immigrants' daughter" who deals with issues of immigration. I was not even trained for that. I rather asked to work in the commission on transports and urban mobility [47].

Rassmea Salah did not want to be stereotyped as the immigrants' child who must necessarily be interested in questions of migration. Ironically, her election was greeted and applauded with a personal message by the then Minister of Integration Cécile Kyenge. During her term, Kyenge, a doctor of Congolese origins, had been the object of much contestation and detestable satire on behalf of Italian racist parties (especially the Lega Party) for the color of her skin. However, also many open-minded people had contested her assignment as "black-immigrant-woman-who-deals-with integration", arguing that she could have been rather employed for her capacity as physician; Rassmea being one of such critics. Therefore, she wanted to avoid the tokenization as a "Muslim who deals with Muslims' problems"; she would rather work on other issues and try to make the most out of this political experience $[47,49,50]$.

The veil is, however, a potent symbol that projected Rassmea on the center stage: she was invited to take part in TV debates and talk-shows because she was veiled and had an "exotic" (i.e., Arab) name, but she had to conceal her real thoughts:

I never declared my sympathy for Hasan al Banna: what I like most about his projects is his welfare policy, the net of educational and healthcare opportunities he provided Egyptians with [ ... ] Had I declared these ideas of mine I would have provoked much stir and contestation [ .... . I I was already accused of being Islamist-phile! I also avoided public comments about foreign politics $[47,51]$.

To my question on how much the veil counted in her being chosen by the Democratic Party, Rassmea answered: "Definitely parties invest a lot on the candidates' image, both aesthetic and social: I was chosen for my social image".

As a double-edged sword, the veil attracts sympathies and enmities to Rassmea, even among the Muslim community:

When I started my appointment I had to shake hands with the mayor, and this provoked much criticism, especially from the converted women's side! They also blamed my attire, as I wore jeans and a long shirt but not fully covering my backside and filled the social media with protests and criticism against me [47].

In any case, Rassmea had to quit her political appointment, as she got married with someone who lives far from Bresso: She kept on going to the meeting while pregnant, but, because of her son's birth and her moving to a city more than 200 kilometers far from the seat of the municipality, she had to resign. She regrets she had to do so because, as she says, she had learnt a lot about administration and public management. However, she is happy because her experience has become a target for many Muslim veiled students who aspire to become involved in politics: 
At the Young Muslims' meetings girls come and question me on how to become a politician: they also ask me to read the speeches they have to read in public. It is a good sign, it means that Muslim girls have learnt how to combine multiple identities, now they can be both respectful of their [veiled] identity and be agents in the public sphere [47].

\section{Other Stories}

Not all veiled women (i.e., with a strong and visible mark of their religious and cultural background) who entered the bastions of Italian politics can boast a positive experience: Aisha Mesrar, a woman of Moroccan origins who served for about three years (2011-2014) as municipal counselor in the affluent city of Rovereto, in North-Eastern Italy, experienced threats and fear. After she had faced the strong and (verbally) violent opposition from the racist parties because she had proposed to build a mosque and a cemetery for Muslims, she began to receive life-threatening letters. After a while, she was forced not only to resign, but also to leave Italy with her family for an unknown destination (2014).

Remarkably, Aisha Mesrar lived and operated in an area known for its tradition of open-mindedness towards the Other. However, these are dark times, and a recent survey has shown that $63 \%$ of the Italian population is against Islam [52]. Especially after the "Islamic" terrorist attacks in Paris (7 January and 13 November 2015), Italy has discovered itself as the European capital of Islamophobia. The rise of terrorism and of the self-proclaimed Islamic Caliphate has dashed away the efforts made in the last decades by many Muslims in order to give a different/better image of their civilization.

To date, the last Muslim and veiled woman to be appointed in a town council was Rabeah Allhaj-yhia, a 43-year-old Syrian cultural mediator who has been living in Italy for more than twenty years. A staunch promoter of her people's rights in these dire times, she was elected in the town she resides in, Altavilla Vicentina (North-East Italy), in a civic list because she does "not want to belong to any party" [53]. Rabeah entered politics because she wants to:

[d]econstruct the myths on Muslim women. We need a change, we need to show that Muslim women are different from the image drawn in Western people's minds. I wanted to show that my religion does not hinder me from agency, from building a better society. The Qur'an is clear in this respect and gives us many samples of active women such as the Pharos's wife, the Virgin Mary, our Prophet's wife Khadija and many others. Here in Italy we need to change the prejudices on Muslim women, they survive because some political men want Italians to think in this way [53].

Will Rabeah succeed in her intent and in her political career? We hope she will, because this would mean everybody's success. At the moment, it is not without preoccupation that I read the comments to the news of her elections in the main local newspapers; comments that underline how her veil is a symbol of backwardness and of the "Muslim invasion" and that lament how she speaks about Syria too much instead of dealing with local issues [54,55].

\section{Conclusions}

The European Union was meant to become a model of supranational organization in which national boundaries had to disappear. However, not only did this ideal goal fail at the outset, but the turmoil that the EU has to face (uncontrollable migration, internal terrorism, economic crisis) has worrisome repercussions on Europe's Muslim populations. Multiculturalism seems to have failed, and Europeans are becoming more and more conservative and unwilling to open space to the "Other", women included. This scenario reinforces the position of individual countries' leaders and parties who want to decide on their own and abandon the idea of a pan-European politics towards minorities, especially Muslims.

On the one hand, the representation of Muslims in European politics has been on the rise in the last decade; among them, a small bunch of (veiled) women is coming forward. However, if we examine 
the situation that has been evolving in the last 4-5 years, we see that it is stepping back again. As terror with an "Islamist" nuance is on the increase and striking Europe, it provokes heavy consequences on people's perceptions of Muslims. Thus, in European countries, veiled women often become the symbol of the internal enemy within national boundaries. As a sample of this situation, I recall here what happened to Rassmea Salah when she moved to Bologna (Italy) in the Summer of 2015: nobody wanted to rent out a house to her because she was veiled and a "foreigner", though both she and her husband were born in Italy, are native speakers of Italian, studied in Italy and work and pay their taxes in Italy.

For what concerns Muslim men and women who live in Italy, the situation could improve by expanding the rights to vote to Muslims who were born/have been living in Italy for decades ([56], p. 98; [57]), if not for justice, for interest: "Islamist" terrorism can only be fought with the help of Muslims, and giving them the possibility to stand out in democratic institutions would increase their chance to overcome the radicals' threat. As for Muslim women, their agency in politics would mean the victory of the "gender issue", for change not only at a theoretical level, but above all, in practice.

Conflicts of Interest: The author declares no conflict of interest.

\section{References and Notes}

1. Westdeutsche Allgemeine Zeitung. "SPD-Politikerin Özoguz Distanziert Sich von Radikal-Islamischen Brüdern." 30 October 2011. Available online: http://www.derwesten.de/nachrichten/spd-politikerinoezoguz-distanziert-sich-von-radikal-islamischen-bruedern-id6030329.html (accessed on 1 November 2015).

2. Green, Simon. "The legal status of Turks in Germany." Immigrants and Minorities 22 (2003): 228-46. [CrossRef]

3. Breuil-Genier, Pascale, Chaterine Borrel, and Bertrand Lhommeau. "Les Immigrés, les Descendants D'immigrés et Leurs Enfants." Available online: http://www.insee.fr/fr/default.asp (accessed on 19 November 2015).

4. Doyle, Jack. “Muslim Labour Frontbencher Accused of Encouraging 'Mob Rule' after Joining Anti-Israel Protest which Forced Supermarket To Close...Then Demanding Goods Boycott." Daily Mail, 19 August 2014. Available online: http://www.dailymail.co.uk/news/article-2729178/Labours-Shabana-Mahmoodaccused-encouraging-mob-rule-anti-Israel-protest.html\#ixzz3qFHfDix5 (accessed on 10 November 2015).

5. Hallam, Kety. "Birmingham MP Attacks City College Veil Ban." Birmimgham Mail, 11 November 2014. Available online: http://www.birminghammail.co.uk/news/local-news/birmingham-mp-attacks-citycollege-5890643 (accessed on 10 November 2015).

6. BBC News. "MPS Support US Air Strikes against IS in Iraq." 26 September 2014. Available online: http: //www.bbc.com/news/uk-politics-29385123 (accessed on 1 November 2015). However, Rushanara Ali was re-elected in 2015.

7. Dabashi, Hamid. “Who is a Muslim?" Al Jazeera, 19 December 2012. Available online: http:/ /www.aljazeera. com/indepth/opinion/2012/12/2012121814265982159.html (accessed on 15 December 2015).

8. The bibliography on women of Muslim origins that serve as "native informants" and the special welcome they enjoy in the West is abundant: See for example, Bahramitash, Roxana. "The War on Terror, Feminist Orientalism and Orientalist Feminism: Case Studies of Two North American Bestsellers." Critique: Critical Middle Eastern Studies 14 (2005): 223-37. [CrossRef]

9. Zine, Jasmin. “Between Orientalism and Fundamentalism: The Politics of Muslim Women's Feminist Engagement." Muslim World Journal of Human Rights 3 (2006): 1-24. [CrossRef]

10. Maira, Sunanina. “'Good' and 'Bad' Muslim Citizens: Feminists, Terrorists, and U. S. Orientalisms." Feminist Studies 35 (2009): 631-56.

11. Dabashi, Hamid. Brown Skin White Masks. New York and London: Pluto Press, 2011.

12. Vanzan, Anna. "Lo sguardo dell'Altra. Donne dell'islam e altri femminismi orientalisti." Altre Modernità 8 (2012): 174-87. 
13. Blumentahl, Max. “Exposing Anti-Islam Author Ayaan Hirsi Ali's Latest Deception. On of America's Most Prominent Islam Bashers Has a Long History of Making Things up." Alternet, 26 March 2015. Available online: http:/ / www.alternet.org/media/anti-islam-author-ayaan-hirsi-alis-latest-deception (accessed on 17 December 2015). For a recent resume of Hirsi Ali's vicissituds, see [14].

14. Heynder, Odile. Writers as Public Intellectuals. Literature, Celebrity, Democracy. Palgrave Studies in Modern European Literature. London: Palgrave Studies in Modern European Literature, 2015, chap. 5.

15. Talhami, Ghada Hashem. "The Legitimacy of the Reformer: The Neo-Cons and Arab and Muslim Women." The Muslim World 101 (2010): 441-63. [CrossRef]

16. In December 2015 Hirsi Ali has been Prized by the Lantos Foundation together with Irshad Manji, Another Muslim woman Whose Main Activity is to Speak and Write against Islam. "Media Advisory—2015 Lantos Prize Laureates Announced." Lantos Foundation, 27 October 2015. Available online: http:// www.lantosfoundation.org/news/2015/10/26/h3mmbhv8h25suysmwq01yabxb1mcmw (accessed on 18 December 2015). Both Ali and Manji have received a variety of honors and prize just for their being (former) Muslims who speak against all the other Muslims.

17. Sbai, Souad. "Souad Sbai dà la Ricetta Anti-Terrorismo: 'Europa Apra Alla Russia, cHiuda Subito a Turchia e Arabia'." Available online: http://www.souadsbai.com/souad-sbai-da-la-ricetta-anti-terrorismo-europaapra-alla-russia-chiuda-subito-a-turchia-e-arabia/ (accessed on 18 December 2015).

18. There is a vast number of projects and studies sponsored by the EU, they can be traced in the EU website dedicated to gender issues. Euroean Commision. "Gender Equality." Available online: http:/ /ec.europa.eu/ justice/gender-equality/ (accessed on 1 March 2016).

19. See for instance the report: European Monitoring Centre on Racism and Xenophobia (EUMC). "Muslim and European Union: Discrimination and Islamophobia." 2006. Available online: http://fra.europa.eu/sites/ default/files/fra_uploads/156-Manifestations_EN.pdf (accessed on 19 December 2015).

20. See official website of the European Union. Available online: www.europa.eu (accessed on 1 March 2016). There are also many calls for funding projects; however, the path to access them is so complicated that hundreds of agencies specialized in filling forms and questionnaires in order to apply for EU funds have come into being in Europe. To decipher the EU website with its "Russian dolls" structure has become an impossible task for the single citizen. On this topic see Fucini, Diana. "Unione Europea e Donne Mediterraneee: Un'analisi Disciplinare dei Programmi Regionali di Assistenza Esterna.” Bachelor's Thesis, Corso di Laurea Magistrale in Relazioni Internazionali Comparate, University of Ca' Foscari, Venice, Italy, 2014. It is also worthwhile noting that, especially in the legislative analysis, the EU programs towards Muslim women do not confirm the prominence theoretically accorded by Europe to gender politics.

21. On this topic see David, Maxine, and Roberta Guerrina. "Gender and European external Relations: Dominant discourses and unintended consequences of gender mainstreaming." Women's Studies International Forum 39 (2013): 53-62. [CrossRef]

22. Merrils, John. The Development of International Law by the European Court of Human Rights. Manchester: Manchester University Press, 1988.

23. For a complete story see Elver, Hilal. The Headscarf Controversy. Secularism and Freedom of Religion. New York: Oxford University Press, 2012.

24. KVINFO. "Asmaa Abdol-Hamid-Her Choice to Wear a Headscarf." 16 May 2007. Available online: http:/ / www.kvinfo.dk/side/674/article/61/ (accessed on 18 December 2015).

25. Euro-Islam.Info. "Muslims in European Politics." Available online: http://www.euro-islam.info/keyissues/political-representation/ (accessed on 4 January 2016).

26. Abdol-Hamid, Asmaa. “To Be a European Muslim Feminist: The Reconciliation of Identities." In Feminist $\mathcal{E}$ Islamic Perspectives. New Horizons of Knowledge and Reform. Edited by Omaima Abou-Bakr. Cairo: The Women and Memory Forum, 2013, pp. 21-24. I met Asmaa Abdol-Hamid during the Conference on Feminism and Islamic Perspectives, New Horizons of Knowledge and Reforms, organized in March 2012 in Cairo by the Women Memory Forum (WMF) and that prompted Omaima Abou-Bakr to collect Asmaa's and other speakers' papers. However, in the present paper I use only the declarations written by Asmaa herself in web articles and in the summoned conference paper.

27. Frandsen, Finn, and Winni Johansen. "Crisis Communication Complexity and the Cartoon Affair: A Case Studies." In The Handbook of Crisis Communication. Edited by W. Timothy Combs and Sherry Holladay. Oxford: Wiley Blackwell, 2012, pp. 425-48. 
28. This famous affirmation is by the late Fatima Mernissi in: Mernissi, Fatima. "Beyond the Veil." In Male-Female Dynamics in Modern Muslim Society, rev. ed. Bloomington: Indiana University Press, 1987, p. 7.

29. On this topic also see Gresch, Nora, Petra Rostock, and Sevgi Kiliç. "Negotiating belonging. Or how a differentiated citizenship is legitimized in European headscarf debates." In Politics, Religion and Gender. Framing and Regulating the Veil. Edited by Sieglide Rosenberger and Birgit Sauer. London and New York: Routledge, 2011, pp. 55-73.

30. Information. "Kaere Asma." 1 September 2007. Available online: http://www.information.dk/145342 (accessed on 2 January 2016).

31. Everything.Explained.today. "Red-Green Alliance Explained." Available online: http://everything. explained.today/Red-Green_Alliance_(Denmark)/ (accessed on 2 January 2016).

32. Wikipedia. "The Red-Green Alliance (Denmark)." Available online: https://en.wikipedia.org/wiki/Red\% E2\%80\%93Green_Alliance (accessed on 4 January 2016).

33. So in Cekic's autobiography. Cekic, Özlem. Fra Føtex til Folketinget. Copenaghen: Gyldendal, 2009.

34. Il Sole 24 ore. "Ecco i Motivi per Cui in Italia i Musulmani Aumenteranno del 103\% in 20 Anni." 16 November 2015. Available online: http://www.ilsole24ore.com/art/mondo/2015-11-15/il-boom-musulmani-italia-passeranno26percento-54percento-popolazione-entro-2030-131517.shtml?grafici (accessed on 4 January 2016).

35. Data may also vary according to the definition of "Muslim", e.g., some statistics include everyone coming from a Muslim country, regardless of their practicing faithfuls; others are stricter in terms of categorization.

36. As of January 2016, in Italy only ius sanguinis is in force but not ius soli: Among the many consequences of this, who is born in Italy from non-Italian parents does not enjoy full citizenship.

37. We have to bear in mind that the position in which the candidate's name appears on the list is crucial in order to obtain visibility and possibly the election.

38. A series of "Islamic" bombing in 2005-2006 had struck the Italian public opinion, in particular that of October 2005 in disco in Bali, a much-coveted turistic place for Italians.

39. Ministero Degli Interni. Available online: http://www1.interno.gov.it/mininterno/export/sites/default/ it/sezioni/sala_stampa/notizie/immigrazione/app_notizia_22030.html (accessed on 4 January 2016). The Consulta has been reshaped many times but with no result, thus the idea to have an institution mediating between the State and the Muslim community failed.

40. Khalid Shouki, a young man of Moroccan origins, was elected PM in the ranks of the Democratic Party (PD). He was also one of the founders of the Giovani Musulmani (Young Muslims) movement (2001).

41. I have known Rassmea Salah for over five years and I am on good terms with her, therefore the interviews I had with her had more the appearance of friendly chats rather than of formal and rigid interviews. In any case, while talking with my informants, though I went "on the flow", I bore in mind a series of basic principles of feminist methodology about interviewing that I always apply to my research: In particular, I followed the suggestions by Hesse-Biber, Sharlene Nagy. "The practice of feminist in-depth interviewing." In Feminst Research Practice. A Primer, 2nd ed. Edited by Sharlene Nagy Hesse-Biber. Los Angeles: Sage, 2014, chap. 7.

42. Lyons, Lenore, and Janine Chipperfield. "(De)Constructing the interview: A critique of the Participatory Method." Resources for Feminist Research/Documentation sur la Recherche Feministe 28 (2000): 33-48.

43. Salah, Rassmea (Milan, Italy). Personal communication, fall 2012.

44. As she declared to me: See Vanzan, Anna, and Le donne di Allah. Viaggio nei Femminismi Islamici. Milano: Bruno Mondadori, 2010, p. 114.

45. Italy is divided into 21 regions that constitute the first-level administrative divisions of the country.

46. See Marc Lazard's opinion: Lazard, Marc. "Per Lazar, 'La Vera Anomalia Italiana è la Gerontocrazia'." Linkiesta, 26 January 2012. Available online: http:/ /www.linkiesta.it/it/article/2012/01/26/per-lazar-lavera-anomalia-italiana-e-la-gerontocrazia/2946/ (accessed on 5 January 2016).

47. Salah, Rassmea (Bologna, Italy). Personal communication, fall 2015.

48. Huffington Post. "Rassmea Salah, a Bresso la Prima Consigliera Col Velo: 'Farò del Mio Meglio'." 13 November 2013. Available online: http:/ / www.huffingtonpost.it/2013/11/13/rassmea-salah-bressoconsigliera-velo_n_4268058.html (accessed on 4 January 2015).

49. On the tokenization of Muslims in European politics see Sinno, Abdulkader, and Eren Tatari. "Muslim in UK Institutions: Effective Representation of Tokenism? " In Muslims in Western Politics. Edited by Abdulkader H. Sinno. Bloomington: Indiana University Press, 2009, pp. 113-34. See also [50]. 
50. Belli, Alessia. "Limits and Potentialities of the Italian and British Political Systems through the Lens of Muslim Women in Politics." In Muslim Political Participation in Europe. Edited by Jørgen S. Nielsen. Edinburgh: Edinburgh University Press, 2013, pp. 163-89.

51. In the popular (meaning uninformed) discourse, the Egyptian founder of the Muslim Brotherhood is considered to be a "fundamentalist" Islamist whose theories are used by the terrorists.

52. Catania, Gabriele. "Il 63\% di Noi è Ostile Ai Musulmani: Italia Capitale Europea Dell'Islamofobia." Gli Stati Generali, 1 December 2015. Available online: http://www.glistatigenerali.com/integrazione/ islamofobia-sei-italiani-su-dieci-sono-ostili-ai-musulmani/ (accessed on 5 January 2016).

53. Allhaj-yhia, Rabeah (Venice, Italy). Personal communication, December 2015.

54. Giornale Di Vicenza. "Rabeha, Prima Candidata Col Velo." 12 November 2015. Available online: http:/ /www. ilgiornaledivicenza.it/territori/vicenza/altavilla/rabeah-la-prima-br-consigliera-br-comunale-col-velo1.4438161 (accessed on 4 January 2016).

55. Corriere del Veneto. “Musulmana Candidata." 22 May 2015. Available online: http:/ / corrieredelveneto. corriere.it/veneto/notizie/politica/2014/22-maggio-2014/musulmana-indossa-hijab-candidata-consigliericomunali-223265988126.shtml (accessed on 4 January 2016).

56. Jytte Klausen reports a figure of 50,000 Muslims having the right to vote in Italy as early as 2009: Klausen, Jytte. "Muslims Representing Muslims in Europe: Parties and Associations after 9/11." In Muslims in Western Politics. Edited by Abdulkader Sinno. Bloomington: Indiana University Press, 2009, pp. 96-112.

57. Jytte Klausen does not give any reference for it. I checked the database of the Ministry of Home Office and there is no statistic of voters according to religion. "Ministero Degli Interni." Available online: http: //www.interno.gov.it/it (accessed on 5 January 2016).

(C) 2016 by the author; licensee MDPI, Basel, Switzerland. This article is an open access article distributed under the terms and conditions of the Creative Commons Attribution (CC-BY) license (http:/ / creativecommons.org/licenses/by/4.0/). 